\title{
AUTENTICIDADE E INSOLÊNCIA PERANTE A IMPESSOALIDADE: UM ESTUDO HEIDEGGERIANO
}

\author{
[ AUtHENTICITY AND INSOLENCE FACING "The THEY": A HEIDEGGERIAN STUDY ]
}

\author{
Lauro Ericksen * \\ Universidade Federal do Rio Grande do Norte, Brasil
}

Resumo: Resumo: Aborda a questão do impessoal como um modo de ser-com os outros, e que se apresenta imbuído, necessariamente, em uma seara de interpretação inautêntica do Dasein. Objetiva, de modo mais amplo e genérico, desenvolver um estudo que localize a prevalência ditatorial desse modo de ser coletivo e como ele promove o decaimento do Dasein na sua cotidianidade inautêntica. Tem por objetivo, especificamente, propor um modo de interpretação autêntico para o modo de ser-com os outros a partir de um posicionamento calcado na insolência perante o impessoal, um modo existencialmente autêntico, que ainda assim seja capaz de se inserir dentro da coletividade postulada nos moldes heideggerianos. Metodologicamente, atêm-se as premissas existenciais de Heidegger contidas em Ser e Tempo e almeja dar o desenvolvimento adequado a partir da formulação desse modo de ser autêntico na coletividade. Resulta que a insolência é um modo de ser-com os outros que suplanta a prevalência do impessoal e supera as amarras da inautenticidade. Conclui que a insolência é capaz de indicar originariamente alternativas existencialmente válidas ao Dasein, ainda que não seja, como os demais modos existenciais apresentados, algo prevalente.

Palavras-Chave: Existencialismo; Dasein; Impessoal; Autenticidade; Coletividade
ABstract: Abstract: The paper discusses the question of "the they" as an existential mode of being-with others, in a way it is pointed as an inauthentical interpretation of Dasein. It intends, in a wider view, to develop a study of "the they" as a dictatorial and decayed mode of being-with others in trivial aspects of life. Specifically, it proposes an authentic mode of being with-others detached from "the they" prevalence, it is based on insolence as a way of colective apporach and comunication with others. Methodologically, it sticks with the exitential premises of Heidegger contained in Being and Time and it shall present the adequate formulation of an authentic colective form of being-with others. It results that insolence is a colective formo $\mathrm{f}$ being that surpass the prevalence of "the they" and also disrupts the chains of inauthenticity. It concludes that insolence is able to originally point valid existential alternatives to Dasein.

KEYwORDS: Existentialism; Dasein; The They; Authenticity; Colectivity

* Doutorado em Filosofia pela Universidade Federal do Rio Grande do Norte, UFRN. Especialista em Direito do Trabalho pela Universidade Cândido Mendes - UCAM/RJ (2010). Bacharel em Direito (2008) pela Universidade Federal do Rio Grande do Norte, UFRN. m@ilto: lauroericksen@yahoo.com.br 


\section{INTRODUÇ̃̃o}

D Dasein é o ente privilegiado na "tradição" heideggeriana que possui vários modos de ser, tanto individuais quanto coletivos. Em sua compreensão "pré-ontológica" da realidade ele consegue se inserir em duas esferas da compreensão, quais sejam: as individualizadas e as coletivas. No trabalho proposto, há o enfoque específico em um dos seus modos de ser coletivo por ele denominado como "impessoal" (ou Das Man, no original em alemão). Esse modo de ser coletivo implicado em ser-com os outros, encontra-se decaído naquilo que Heidegger costumou indicar como sendo a "inautenticidade". Isto decorre, basicamente, por causa da cotidianidade e do elemento ordinário a ele associado, outrossim, o modo mais comum e trivial de ser-com os outros (em detrimento de qualquer outro modo de ser coletivo "autêntico").

Por ser o mais elementar dos modos de ser-com os outros, o impessoal é o ponto de partida para se questionar a outra ponta da questão, algo que Heidegger apenas deixou ventilado em Ser e Tempo, mas que não adentrou nem tratou detidamente desse assunto: é possível sair da inautenticidade coletiva para se chegar a um modo autenticamente coletivo de convivência? Desde logo, por causa da ausência de clareza e aprofundamento desse filósofo, um apontamento metodológico torna-se salutar: será necessário e inequívoco recorrer a comentadores para que o questionamento levantado possa ser respondido a contento, não sendo bastante apenas repetir o elenco vago posto pelo próprio Heidegger sobre esse tema. Dessa forma, opera-se um recorte metodológico essencial, que não tem o escopo de agregar um todo "sistemático" dentro da obra (Ser e Tempo) ou quiçá de outras obras do mesmo autor, e, sim, foca-se em buscar uma via própria e alternativa da questão posta como relevante a ser debatida.

O questionamento anteriormente levantado se torna ainda mais capcioso e mais complexo de ser respondido quando se tem em relevo que toda a compreensão antimetafísica do Dasein tem como pano de fundo o próprio homem (individualmente colocado), e não propriamente uma indicação coletiva do Dasein. Mesmo diante de tal dificuldade e desafio, o presente trabalho visa perscrutar a possibilidade existencial de se desvencilhar das amarras do impessoal para se chegar a um modo de ser coletivamente autêntico, algo sequer aventado pelo próprio Heidegger em Ser e Tempo, saliente-se.

Didaticamente, o artigo possui, além dessa introdução, mais três seções, incluindo-se nessa contagem um breve fechamento do tema em termos de considerações finais sobre o assunto debatido. A seção subsequente tem o intento de demonstrar como o impessoal, sendo um modo de ser-com os outros, opera a partir de um decaimento inautêntico do Dasein em sua cotidianidade e em seus entremeios triviais, e como que esse modo de tratar os outros impessoalmente acaba por ser uma imposição ditatorial e aprisionadora dessa forma de ser coletiva.

A quarta seção do trabalho objetiva de modo primordial oferta uma possibilidade existencial que opere um trespasse no aprisionamento do impessoal como modo de ser inautêntico. Assim, nessa seção, vislumbra-se a possibilidade de se pensar como um modo de ser insolente perante a impessoalidade cotidiana é capaz de se converter, autenticamente, em um modo de se pensar a convivência cotidiana em uma relação de (auto) consciência, do Dasein em-si mesmo e para si-mesmo. Um modo de ser, ainda que coletivo, mas que supere as limitações da inautenticidade pujante nas relações entre o Dasein e os outros que o circundam em sua lida cotidiana, ampliando, dessa maneira, os seus horizontes existenciais mais originários em sua compreensão de si e de mundo. 


\section{O IMPESSOAL COMO MODO INAUTÊNTICO DE SER-COM}

Inicialmente, há de se colocar que o impessoal (Das Man) não está simplesmente solto dentro do estudo de Heidegger acerca dos modos de ser do Dasein como sendo algo meramente desconexo com os demais modos, como se a sua colocação fosse despicienda, levando em conta o conjunto de modos de ser por ele colocados em desenvolvimento de uma pretensa antropologia filosófica. Nessa toada, há de se observar que o impessoal é um dos constitutivos do fenômeno da decadência (Verfallensein). Há de se pontuar, de maneira quase que propedêutica, que a decadência encontra-se em alinhamento com a "existencialidade" e com a "facticidade", para findar por formar a tríade de caracteres existenciais do Dasein.

O impessoal é denominado por Heidegger (1967, p. 176) como o Das Man, termo em alemão que, literalmente, quer dizer "o um". No entanto, na tradução para o português se optou por escolher traduzi-lo por "impessoal”. Na tradução em espanhol da obra em comento, Ser y Tiempo (HEIDEGGER, 2005, p. 152) usa-se um termo bastante próximo do original em alemão: El Uno para designar o Das Man. Semelhantemente, na tradução em francês da obra heideggeriana (Être et Temps), o termo em comento é traduzido como Le On (HEIDEGGER, 1985, p. 126). Na tradução em português, diferentemente das outras analisadas (a outra tradução em que o sentido é alterado substancialmente, é a inglesa, na qual se traduz Das Man por The They), perde-se um pouco o sentido unitário do impessoal, haja vista que esse termo não remete, ao menos diretamente, aos comandos uniformizadores desse modo de ser inautêntico.

O grande problema com a tradução feita em português como sendo "impessoal" remete a questão de a "pessoalidade" (do latim, persona) não ser um atributo unicamente humano, pois, ela pode ser um atributo meramente artificial criado pelo próprio homem, a exemplo do que ocorre com as pessoas jurídicas1x. Assim sendo, a impessoalidade finda por ser um termo que não denota especificamente a uniformização causada pelo Das Man, em seu sentido original, e também finda-se por ser imprecisa na indicação de que a coletividade do Dasein (e não de patrimônios, entes simplesmente dados), tampouco elucida a possibilidade dessa forma inautêntica de poder assumir uma proposição ditatorial, como será avaliado mais adiante. Todavia, ainda assim, há de se salientar que a tradução por "impessoal" na língua portuguesa terá uma repercussão linguística interessante, a qual será analisada mais adiante.

O foco na presente seção se encontra em analisar como se dá o "processo" de decadência do Dasein, e como que este modo de ser se apresenta envolto pelas perspectivas coletivas. Ou seja, há de se perscrutar como esse modo de ser coletivo não somente influencia, bem como finda por controlar toda e qualquer ação do Dasein, ainda que de maneira dualmente posta. Nesse ponto, pode-se questionar, acertadamente, se uma existência autêntica implica, de alguma forma, ainda que não necessária, uma existência coletiva (que seja também autêntica). Certamente, essa é uma questão metodológica na abordagem do texto heideggeriano, e como já indicado na introdução, o autor debatido é bastante sucinto ao tratar das possibilidades coletivas do homem, e nem sequer adentra numa proposta de coletividade autêntica, ao contrário do que ele propõe ao debater a existência autêntica (individualizada).

Dessa forma, Heidegger não pontua claramente que de um ponto (existência autêntica) se deriva o outro (coletividade autêntica). No entanto, como um dos postulados básicos da compreensão pré-ontológica do ente denominado Dasein se centra na questão de suas possibilidades existenciais, descortina-se, ao se poder 
vislumbrar uma existência autêntica (ainda que individualizada), a possibilidade de se debater uma coletividade autêntica. É justamente nesse fio de possibilidade (em seu sentido diferenciado ontologicamente da própria individualidade) que o tema é desenvolvido nessa seção e também nas demais.

Existe uma disposição constitutiva de forma ditatorial do impessoal (indicada pelo afastamento, a medianidade e o nivelamento por ele impostos, três termos conceituais apontados por Heidegger). Essa é uma das grandes contribuições heideggerianas ao estudo dos modos de ser coletivizados, embrenhados no parágrafo 27 de Ser e Tempo. Essa gerência ditatorial do impessoal tem algumas repercussões importantes que necessitam ser efetivamente escrutinadas. Outrossim, sob outro prisma, é possível se desvencilhar das amarras do impessoal para que se deduza uma coletividade autêntica? Essa talvez seja a questão mais exponencial de toda a exposição, a qual será o imbróglio final a ser debatido na presente análise, e, que, após a sua elucidação, será possível compreender fenomenologicamente como ambos os modos de ser cooperam para a formação dos modos de ser do Dasein, segundo as premissas heideggerianas.

Por derradeiro, há de se analisar como é possível que o Dasein venha a apresentar um modo de ser que o possibilite a ser autêntico em seu espectro decisório comunitário a partir de toda a sua imersão na impessoalidade. Destarte, será apresentado o conceito de insolência (do alemão: Selbstherrlich), o modo de ser, através do qual, o Dasein se posiciona e adota uma postura resoluta perante o domínio impositivo do impessoal, determinando como ele poderá, a partir de então, interpretarse em seu próprio horizonte de finitude, compreendendo, desta maneira o seu si-mesmo mais próprio. Essa é a chave elucidativa da diferença ontológica posta entre o ser-com os outros inautenticamente e a sua modalidade autêntica, disposta como verdadeira para o próprio Dasein.

A partir dos contornos do modo de ser insolente perante o domínio ditatorial do impessoal, o Dasein passa a não estar mais afeito, de maneira pré-determinada e a ele co-relacionada, a todas as prescrições normativas de condutas da inautenticidade inserta no impessoal. De acordo com essa premissa, o Dasein passa a poder ser propriamente si-mesmo, não apenas em sua própria concepção de ser em si-mesmo, mas também em sua compreensão de ser-no-mundo, o que o possibilita a apresentar-se, originariamente, para com os outros, comunitariamente se compreendendo, e podendo ser, desta feita, autêntico também nesses meandros coletivizados. Afinal, sem tal apresentação insolente, os meios coletivizados em que o Dasein se inseriria seriam apenas reflexos da inautenticidade do modo de ser impessoal do qual ele cotidianamente é refém.

O Dasein e as suas possibilidades de ser autêntico: Insolência (Selbstherrlich) e entendimento autêntico de mundo

Ainda que se trilhe acuradamente todas as ponderações feitas anteriormente, há de se ter em conta que não se pode dar uma única conotação "negativa" ao impessoal, haja vista que, ainda que a imagem comumente pintada desse modo coletivo seja essa. O impessoal não é algo estranho ao Dasein ou algo em que o Dasein decai ocasionalmente (pelo contrário, na maior parte das vezes ele está na impessoalidade), daí decorre que é algo usual e corriqueiro, e não algo necessariamente negativo. Mesmo que se ventile a possibilidade de retorno para o ser si mesmo mais verdadeiro e autêntico, ainda assim apenas se modificou o impessoal no próprio Dasein (ou melhor, como esse modo de ser com os outros é por ele assimilado). O homem sempre descobre, num primeiro momento, a si mesmo não como "si mesmo", mas como o impessoal em "si mesmo", ou seja, a ótica de sua própria compreensão é estabelecida 
pelo impessoal. Vivendo uma vida não por si (sendo inautêntico em seu cotidiano), ele pode alcançar e revelar seu si mesmo.

Essa revelação é acompanhada pela remoção do ocultamento e das obscuridades, esmagando as barreiras do Dasein ser o si mesmo de si mesmo. Nesse horizonte, como bem salienta Vincent Vycinas (1969, p. 43) "o modo inautêntico de existir é necessário para que provisione as bases nas quais o modo autêntico de ser possa ser construído". Depreende-se, portanto que a autenticidade não é nada mais que uma inautenticidade modificada, todavia, essa não é uma indicação existencial que se se torna perfeita naturalmente, é necessário que as bases ontológicas dessa mudança sejam perscrutadas, e é justamente tais nuances que são apresentadas no desenvolvimento desse trabalho.

Seguindo essa mesma premissa de que há uma conexão inarredável entre a autenticidade do ser-com e a inautenticidade do impessoal, Hervé Pasqua (1993, p. 65) pondera que "é na individualidade (ipsiedade) inautêntica a partir da qual o si mesmo autêntico deve emergir comunitariamente". Dessa maneira, por mais que o impessoal seja dado "inautenticamente" a todos, como um comando de uma indeterminação coletivizada, o Dasein permanece nele individualmente absorto, sem ser-com os outros autenticamente, saliente-se, nesse ponto, que essa interpretação de Pasqua não é derivada diretamente do texto heideggeriano, ela já é um desdobramento possível sobre o qual esse comentador se arvora para desenvolver o tema dado.

Deve-se atentar, portanto, que há uma conjunção entre a inautenticidade e a autenticidade para que essa última possa emergir, devendo-se salientar, que ela só pode emergir da própria inautenticidade, e isso ocorre basicamente por dois motivos que serão mais bem explanados a seguir.

$\mathrm{O}$ primeiro deles diz respeito à transição entre a individualidade inautêntica e ao caráter comunitário da autenticidade, como bem posto em relevo por Pasqua, dando-se uma forte inclinação à coletivização comunitária do Dasein. O segundo motivo reside na própria prevalência do impessoal, ou seja, partindo-se do princípio que ele é a primeira interpretação de mundo do Dasein, e que nessa forma decadencial o Dasein permanece a maior parte do tempo, não haveria, por uma questão de persistência da inautenticidade do impessoal, como o Dasein não estar nele lançado, e, assim, por conseguinte, viesse posteriormente a nele se inserir. Uma situação como esta denotaria que o Dasein estava na autenticidade, em primeiro plano, mas que acabou por decair na impessoalidade. O cenário descrito não é totalmente improvável, aliás, é comum até mesmo que após o vislumbre da autenticidade, o Dasein retorne aos meandros da decadência, no entanto, a implausibilidade de tal escrutínio reside na colocação em primeiro plano da autenticidade.

Se assim o fosse, o que aconteceria é um modo de ser ao contrário do que foi descrito. O Dasein se encontra, a princípio e a primeiro modo em sua impessoalidade, despejado na sua inautenticidade, só então é possível que se vislumbre que ele adentre na autenticidade, e, em consequência consiga visualizar o seu horizonte interpretativo temporal comunitariamente posto diante de si. Inverter as ordens de tal colocação fenomenológica não se afigura possível, dada a recorrência impositiva do impessoal e de sua dispersão determinativa decadencial, algo que não dá azo ao Dasein ser, primeiramente, autêntico sem ter estado previamente decaído na própria impessoalidade que é tão comum e corriqueira em sua cotidianidade.

Seguindo esse passo, há de se ter em conta que a presente dissertação caminha no sentido do entendimento esposado por Róbson Ramos dos Reis (2001, p. 126), ao dizer que "a modificação para a autenticidade ainda é fundada na socialidade do Dasein, porque diz respeito a uma mudança na relação com a impessoalidade". Ou seja, 
ao se alterar o modo de ser do Dasein da impessoalidade para a pessoalidade, há de se ter um fundamento comunitário presente, qual seja, a sua própria sociabilidade com os outros. Sem essa interação existencialmente autêntica do Dasein com o outro (com aquele outro com quem ele exercita seu modo de ser-com - os outros), não há horizonte plausível para uma coletividade autêntica a partir do entendimento heideggeriano.

Heidegger até mesmo suscita a possibilidade de o Dasein "descobrir o mundo, aproximar-se de si e abrir-se para si mesmo, para o seu próprio ser", ainda que ele esteja decaído na impessoalidade pujante dos contornos da lida cotidiana. E para tal, ele aponta, muito vagamente, que é necessário "uma eliminação das obstruções, encobrimentos, obscurecimentos, como um romper das distorções em que o Dasein se tranca contra si mesmo" (HEIDEGGER, 2008, p. 187). Assim, Heidegger aponta o caminho, mas não escrutina como é esse modo de ser de retomada da autenticidade a partir do decaimento no impessoal, ele apenas vislumbra que isso é possível, e a maioria dos seus comentadores $2 \mathrm{x}$ indicam que isso se dá através de uma mudança no elemento social de sua interação com os outros. Todavia, nesse ponto, ainda resta uma lacuna a ser mais bem analisada e, possivelmente, colmatada.

Dada a inescapável inserção no próprio impessoal, o Dasein se vê dotado, de um termo ainda a ser impregnado nessa perspectiva analítica heideggeriana, de uma insolência de sua própria condição mais autêntica de ser. Há de se explicar que o referido termo advém da tradução do alemão da palavra Selbstherrlicht, a qual, no presente estudo, traduzir-se-á por "insolência". Na linguagem coloquial, o termo insolência, por vezes, refere-se à elevação de um determinado indivíduo de sua condição, ou que seja, no mínimo, totalmente absorto dela e faça o que lhe convém (como se fosse uma espécie de Hybris3x), no entanto, nenhuma dessas perspectivas há de ser posta em análise por não condizerem com o sentido heideggeriano a seguir de norteamento para se perscrutar essa questão.

É comum se observar que o termo Selbstherrlich também seja traduzido comumente por "autocrático". Todavia, tal tradução finda por sugerir um elemento de solidão a esse "poderio autônomo", um exemplo de tal tendência é afirmada pela tradução feita por Clifford J. Green (1999, p. 113) ao tentar descrever "os ecos de um mundo auto-dominado e auto-interpretado". Pugna-se, como o faz Jan Mieszkowski (2006, p. 68) que "autocracia" em alemão é "mais bem expressa pelo termo Eigenmächtig”. Há de se pontuar que existe também quem busque traduzir o termo em comento por "tirânico", como o faz Peter C. Caldwell (1997, p. 159), no entanto a sua abordagem parte de uma premissa jurídico-política (ou melhor, normativo-política), a qual não é a mais interessante, tampouco a mais relevante para se ter em referência à tradução desse termo a ser aplicada em uma esfera hermenêutica eminentemente ontológica como o é a obra heideggeriana, dadas as disparidades de suas contextualizações. Desta feita, opta-se pela tradução do termo como sendo insolência por não possuir um caráter excessivamente dogmático quanto o termo "autocracia" e também não é político-impositivo como seria a sua tradução por "tirania".

A origem alemã da palavra em relevo remonta à concepção de que há uma negociação da "identidade" do homem, em um resgate hegeliano, no sentido de que ele é "senhor" e "mestre" sobre si mesmo (Cormican, 2009, p. 99). Nesse sentido, denotase a partir de seu uso que, diante das circunstâncias impositivas do impessoal, e de sua ditadura preconizadora de formas de interação entre o Dasein e os outros, há como desobstruir os encobrimentos dessa forma autêntica de ser. Isso ocorre, pois, tendo-se em referência o próprio senhorio dos modos de ser, ainda que atrelados ao cotidiano, é possível ser insolente com o impessoal e com as suas variáveis determinações, ainda 
que historicamente ele tenha fornecido as primeiras interpretações do mundo circundante.

Para que o Dasein possa se projetar autenticamente no mundo a ser descoberto, é imperioso que ele tenha a "predisposição" $4 \mathrm{x}$ de se mostrar insolente. Tal insolência deve ser dirigida, especificamente, para aquilo que lhe é mais comum, mais trivial e mais banal, a sua própria visão de mundo impessoalmente dada, medianamente "construída", e nivelada sempre segundo os padrões que excluem a sua possibilidade mais originária de ser-si-mesmo. Pode parecer algo absurdamente difícil conseguir exibir um modo de ser que seja o detentor de tão "portentosa" insolência, haja vista que, cotidianamente, o impessoal prescreve as regras de conduta, as formas como se deve interagir com os outros e como todas as demais situações triviais devem ser postas e executadas. É como se não sobrasse nenhum espaço sequer para que a autenticidade fosse "insolentemente" exercitada, o impessoal a tudo e a todos ocupa, daí essa impressão de asfixia que a inautenticidade provoca ao entendimento mediano de tais ocorrências comuns.

Ser insolente é ser-si-mesmo em detrimento de todas as imposições ditatoriais do impessoal. É ter a noção de que, embora o impessoal delineie a interpretação de mundo mais imediatamente posta - a instantaneidade da determinação advinda do impessoal é bastante relevante do ponto de vista que elas se apresentam como única forma de interpretação do mundo e que sequer existem outras formas de proceder. Daí a necessidade de se compreender que, por mais que as determinações e imposições do impessoal sejam presentes, elas não são as únicas a serem vislumbradas e projetadas pelo Dasein, principalmente quando ele apresenta o modo de ser autêntico e resoluto de suas próprias possibilidades existenciais. Assim, ela não é a única a ser alcançada pelo Dasein em toda a sua possibilidade de ser autêntico. É um modo de ser autêntico em si mesmo sem ser atingido por aquilo que é trivialmente exposto, dado e suscitado pelos meandros da inautenticidade (HEIDEGGER, 2008, p. 358). É uma forma de ser aquilo que se é possível ser autenticamente, é a insolência que serve de combustível para se sair da inautenticidade em busca da própria autenticidade. É um "finitizar" $5 x$ independente de qualquer prescrição normativa do impessoal, é um olhar afastado daquilo que afasta, é o contraponto da determinação previamente dada em confluência com aquilo que pode ser descoberto na abertura de ser-si mesmo e para si-mesmo. Em síntese, é o modo de ser que se alcança o si mesmo mais autêntico e mais próprio do Dasein em sua saída eruptiva da impessoalidade reinante na cotidianidade, é a diapasão existente entre a cotidianidade e a autenticidade mais própria do Dasein. Nesse passo, há de se concluir que se destitui o impessoal de seu domínio por meio desse modo de ser insolente do Dasein de maneira incisiva e apropriadora, uma autêntica retomada do ser si mesmo próprio que estava "adormecido" nas premissas da impessoalidade.

Há de se ter em mente que apresentar um modo de ser insolente, por parte do Dasein, é uma forma de ser intermediária, ou em vistas de ser algo (particularmente, atingir a autenticidade), ou seja, possui uma finalidade bastante definida. Todavia, esse modo de ser não apresenta uma mera transitoriedade aparente, afinal, quando a autenticidade é expressa como um modo de ser autêntico do Dasein, nada garante que ele não venha a decair novamente para a impessoalidade. Sendo certo que, enquanto ele se suster, propriamente, de modo a ignorar as prescrições determinantes da impessoalidade, ele se manterá autêntico, e, por conseguinte, reverberará ainda mais a sua insolência como um modo de ser existencialmente posto. A finalidade posta à insolência, no entanto, não finda por recair em algum esquema lógico, como haveria de se pressupor se o impessoal fosse um gênero nos moldes aristotélicos, a sua consecução 
final é apenas o entremeio do alcance da autenticidade do Dasein. Dito de maneira mais clara, como Heidegger não dimensiona o modo como o Dasein pode transitar entre a inautenticidade e a autenticidade, embora ele mesmo admita que isso seja possível, a insolência surge como modo de ser a colmatar essa lacuna, direcionando, nesse sentido,

o Dasein para a sua autenticidade e para o seu si mesmo mais próprio.

Nesse compasso, a insolência é uma forma de escrutinar, de forma a restituir, a "realidade do nosso ser" (TURK, 2008, p. 115), a qual pode ser desvelada ao Dasein por meio desse modo de ser em busca de sua autenticidade. Em virtude da possibilidade de o Dasein poder tanto estar em sua verdade quanto em sua "não-verdade", o ponto de transição entre o desvelamento da sua verdade compartilhada com os outros, depende, em primeiro plano, que ele consiga abjurar todo o conteúdo impositivo do impessoal. Isso ocorre em virtude da prevalência e da persistência dessas formas ditatoriais de interação do impessoal. Dessa forma, caso o Dasein esteja resoluto de sua insolência perante tais comandos impessoais conseguirá deles se desvencilhar para que os outros e os demais entes a ele se desvelem autêntica e verdadeiramente.

Diante dos elementos descritivos aplicados à insolência do Dasein, pode-se pensar que esse modo de ser, de alguma forma, pareça-se com aquilo que Heidegger (2008) denominou resolução. O Dasein resoluto, não é nada diferente daquele que se decide por algo. Já o modo de ser insolente do Dasein significa que ele decidiu-se por não estar mais decaído impessoalmente e que decide ser resoluto em sua autenticidade. $\mathrm{Ou}$ seja, a insolência finda por ser uma forma desenvolvida da própria resolução decisória do Dasein. Como comentado anteriormente, o impessoal retira o fardo decisório do Dasein ao lhe ofertar formas pré-concebidas e pré-moldadas de decisão, assim sendo, ele não precisa se ocupar dos entes no mundo e tampouco precisa se preocupar com os outros. O impessoal sempre lhe fornece uma decisão que the retire essa responsabilidade de se decidir por isso ou por aquilo, ainda que o "isso" ou o "aquilo" não estejam previamente pensados pelo próprio Dasein.

Nesse passo, ser insolentemente resoluto quer dizer que o Dasein recapitula a sua possibilidade decisória mais autêntica ao rejeitar as decisões já prontas do impessoal e ao passar a descortinar, ele mesmo, as suas possibilidades decisórias mais existencialmente originárias, aquelas que lhe mostram, efetivamente, o seu si-mesmo próprio e autêntico. Ao se decidir por não mais ser condizente com as propostas traçadas pelo impessoal, o Dasein (autenticamente) em sua forma individualizada se abre para o debate coletivo e se projeta nessa nova esfera de possibilidades existenciais, abrindo, assim, caminho para um Dasein coletivo autêntico, por conseguinte.

A insolência do Dasein para com o impessoal quebra a neutralidade desse modo de ser inautêntico, ela finda por demover as barreiras montadas pelo seu caráter neutro, possibilitando, reiteradamente, que o Dasein lance-se (projete-se) no seu si mesmo mais próprio, o qual não mais estará (ao menos, necessariamente) atrelado aos "padrões medianamente impostos pela publicidade constante no modo de ser cotidiano" (HEIDEGGER, 2008, p. 283). O impessoal perde seu domínio a partir desse novo modo de ser em desacordo com as suas premissas niveladas, nas quais a uniformização é predominante. Ao se portar insolentemente o Dasein deixa de ser "mais um" na uniformidade do nivelamento proposto pelo impessoal, e, assim, deixa de perpetuar a inautenticidade característica desse modo de ser decadente, para que possa ser autêntico e aberto as mais variadas possibilidades de seu si mesmo.

Concernentemente a essas ponderações acerca da relação entre a insolência e a impessoalidade (de como elas se inter-relacionam), fica bastante claro como que a insolência faz a ligação de imposição determinativa do impessoal para as possibilidades 
mais autênticas do Dasein. Há de se salientar que ao reter tais possibilidades insolentemente, e assim, rumar para a sua autenticidade, o Dasein finda por resgatar a sua responsabilidade, o que o remete, propriamente, a concepção de que o "Dasein está em débito"6x (HEIDEGGER, 2008, p. 360) - do original em alemão: Schuld - com a sua própria existência. Não obstante, há de se compreender que a dívida do Dasein não é uma espécie de "dívida com a sociedade", como comumente se diz a respeito dos detentos e presidiários que, após cumprirem suas respectivas penas, voltam ao convívio social, ou seja, voltam a conviver em sociedade depois de terem pagado seu débito social por terem cometido um ato penalmente ilícito. Contrariamente, essa dívida não possui uma extensão para toda a sociedade, como se fosse uma retribuição que o Dasein tivesse que dar para ela, em forma de uma troca recíproca de favores. A dívida do Dasein, ainda que possa ser algo dele que se projete no outro, é algo prioritariamente seu, que diz respeito a sua própria existência, e não algo concernente a uma "sociedade" universalmente posta, e, que estaria capacitada a cobrar dele tal inadimplência.

Nesse diapasão, percebe-se que o Dasein está em débito por não corresponder as possibilidades autênticas do seu si mesmo, algo que é exposto a ele pelo seu modo insolente de ser diante da impessoalidade da cotidianidade em que ele se encontra inserido. Ou seja, o débito decorre da inadimplência do Dasein com aquilo que ele é, ou seja, decorre do "eu sou" propriamente dito (HEIDEGGER, 2008, p. 361). Todavia, essa dívida do Dasein para consigo mesmo, não se dá, unicamente, de forma colapsada em sua individualidade. Pois, concomitantemente, enquanto se está em débito com a sua própria existência, o Dasein também está em débito com os outros, haja vista que eles não são a simples soma dos demais além do si mesmo.

A compreensão acima exposta é a ligação primordial que existe entre a questão do modo de ser insolente do Dasein e sua autenticidade para com a sua interpretação autêntica dada comunitariamente, ou seja, é o modo como se conectam a insolência perante o impessoal e o modo de ser-com os outros autenticamente. Sem essa interligação não haveria como se pressupor (de forma acertada) que o modo de ser comunitário, autenticamente, mantém qualquer relação com o modo de ser a partir do qual o Dasein se liberta do impessoal e pode ser si mesmo, de maneira própria e originária, também com os outros.

Desta feita, percebe-se como todo o desenvolvimento do tema se encontra interligado, questão decisória, em seu viés comunitário está devidamente atrelado ao modo de ser do Dasein que o retira da impessoalidade e o possibilita novamente se descortinar no horizonte do seu entendimento resoluto e autêntico. Assim, a necessidade de abordar essa temática se revela ainda mais ressaltada quando se percebe que Heidegger até dá indicações sobre a possibilidade de o Dasein sair de sua inautenticidade impessoal e se interpretar autenticamente, embora não coloque como isso pode acontecer. Esse poder-acontecer, portanto, afigura-se escrutinado pela forma de se portar da insolência perante os domínios cotidianos da impessoalidade, através desse modo de ser o Dasein resgata a sua possibilidade mais autêntica de ser si mesmo, principalmente porque isso diz respeito a ele e aos outros.

Por fim, há de se repisar apenas o ressalte comunitário ao qual o modo de ser insolente do Dasein conduz. Sem essa faceta pautada em uma autenticidade comunitariamente posta, seja ela em uma colocação de um círculo cultural, ou de qualquer outro agrupamento do mundo fenomenologicamente social pensado por Heidegger, seria até mesmo despiciendo levantar toda essa problemática em sua filosofia, mais especificamente ao se voltar aos seus escritos em Ser e Tempo. Essa é a conclusão necessária para que se possa perceber o quanto esse modo de ser insolente do 
Dasein é desafiador e finda por guiar o Dasein no caminho de poder escrutinar, ainda que de modo tautológico, as suas próprias possibilidades de seu "poder-ser" e de seu si mesmo mais originário e autêntico. Sem essas ponderações, em conjunto e consonância com as possibilidades comunitárias (já insertas nesse contexto de fornecimento de um horizonte interpretativo mais próprio), não haveria como sequer se pensar as formas autênticas de ser quando colocadas e pensadas em detrimento da ditadura e das demais formas impositivas postas de forma inautêntica pelos domínios recorrentes da impessoalidade cotidiana.

Em síntese, há de se compreender que, por mais que o Dasein esteja decaído nos meandros da inautenticidade, e que essa seja a sua primeira noção de mundo, isso não impede que ele seja autenticamente ser-com os outros, tampouco tenha que abraçar a impessoalidade cotidiana como único e finalístico modo de ser si mesmo.

\section{CONSIDERaÇões FinAis}

Derradeiramente, o artigo em desenvolvimento há de indicar que dentre as possibilidades existenciais virtualmente postas diante do Dasein é necessário que ele se compreenda como um ser-no-mundo finito em seu horizonte de possibilidades para que se possa vislumbrar uma apropriação autêntica do seu modo de ser coletivo. Inicialmente, o Dasein sempre está fadado ao seu modo de ser-com os outros de modo inautêntico, sempre decaído em sua cotidianidade factual, um contexto existencialmente despido de qualquer aspiração mais originária em sua forma de ser coletiva. Essa apresentação coletiva acaba por assumir um caráter ditatorial em sua lida cotidiana, ele não consegue se compreender autenticamente porque sempre decai em tal forma corriqueira e cotidiana de convivência com os outros, sem que lhe seja dada (ou ofertada de pronto) nenhuma margem de manobra para que possa haver um vislumbre existencial mais próprio ou mais originário.

É necessário, para que se possam subverter as amarras cotidianas e decaídas do impessoal, que o Dasein se liberte insolentemente de tal contexto inautêntico. Pensar as suas formas coletivas de organização em detrimento de sua compreensão de mundo cotidiana e comezinha é indispensável para que a insolência (Selbstherrlich) se afigure como um modo de ser coletivamente autêntico em oposição ao impessoal. Esse modo de ser autêntico projeta-se de modo dual tanto para-si quanto por-si, fazendo com que o Dasein consiga atingir um nível de (auto) consciência apartado da sua mera lida cotidiana e impessoal, que é o modo de ser adequado para a sua zona de conforto habitual e corriqueira, algo que a princípio ele nem sequer cogita superar.

Através da apresentação da insolência como modo de estruturação de um Dasein coletivamente ativo é possível se pensar todas as possibilidades existencialmente válidas para uma tomada de decisão que não implique apenas um aparte autêntico de cada um, mas que possa repercutir válida e perenemente em todos os indivíduos que integram uma mesma comunidade e possuam os mesmos desígnios de vida cotidianos. A saída da inautenticidade, em um modo de ser-com os outros, portanto, afeta não apenas a individualização do Dasein, bem como todo o seu entorno coletivamente dado. Dessa feita, a insolência perante a ditadura do impessoal não é perpetrada de um só turno por apenas um ente individualizado, mais que isso, ela é a força de um modo de ser coletivo que desperta de decaimento profundo inautêntico para poder se pensar, a si mesmo e para si mesmo, coletivamente em todas as suas tomadas de decisões mais próprias e mais originárias perante a sua existência. 


\section{Referências}

CALDWELL, Peter C. Popular sovereignty and the crisis of german constitutional law: The Theory and Practice of Weimar Constitutionalism. Durham: Duke UP, 1997.

CORMICAN, Muriel. Women in the works of Lou Andreas-Salomé: Negotiating Identity. Rochester: Camdem House, 2009.

DALBOSCO, C. A. O cuidado como conceito articulador de uma nova relação entre filosofia e pedagogia. Educação e Sociedade, Campinas, v. 27, n. 97, p. 1113-1135, 2006.

GREEN, Clifford J. The Sociality of Christ and Humanity: Dietrich Bonhöffer's Early Theology. Grand Rapids: B. Eerdmans, 1999.

HEIDEGGER, M. Etre et Temps. Trad. Emmanuel Martineau. Paris: Authentica, 1985. . Sein und Zeit. Tübingen: Max Niemayer, 1967. Ser e Tempo. Trad. Márcia Sá Cavalcante Schüback. 3. ed. Rio de Janeiro: Vozes, 2008. Ser y Tiempo. 4. ed. Trad. Jorge Eduardo Rivera Cruchaga. Santiago: Universitária, 2005.

LOPARIĆ, Z. Sobre a responsabilidade. Porto Alegre: EDIPURS, 2002.

MIESZKOWSKI, Jan. Labors of Imagination: Aesthetics and Political Economy from Kant to Althusser. New York: Fordham UP, 2006.

NYUSZTAY, Iván. Myth, Telos, Identity: The Tragic schema in Greek and Shakespearean Drama. Amsterdam: Rodopi, 2002.

PASQUA, Hervé. Introduction à la lecture de Etre et Temps de Martin Heidegger. Lausanne: L'Age d'Homme, 1993.

REIS, Róbson Ramos Dos. O ens realissimum e a existência: Notas sobre o conceito de impessoalidade em Ser e Tempo, de Martin Heidegger" Kriterion, Belo Horizonte, v. 42, n. 104, p.113-129, 2001.

TURK, Horst. 'Mooristan' und 'Palimpstine': Die Integration Europas ein Vebanquespiel säkularisierter Monotheismen? In: BARBEITO, José Manuel (Org.). Nationale Identitäten und europäische Literaturen. Bern: Peter Lang, 2008.

VYCINAS, Vincent. Earth and Gods: An Introduction to the Philosophy of Martin Heidegger. The Hague: Martinus Nijhoff, 1969.

\section{Notas}

1 Sinteticamente "pessoa jurídica é uma junção de pessoas naturais ou de patrimônio tendo em vista a obtenção de certos fins, a partir dos quais se tem reconhecimento pelo ordenamento jurídico", sendo, portanto, "sujeito de direitos e obrigações" (BICCA; Noronha, 2006, p. 67). Ou seja, ela é uma mera intelecção da produção do pensamento humano, um feixe de contratos e direitos dispostos sem nenhuma base material ou "substancial", por assim dizer, sem um lugar no "mundo", em um sentido heideggeriano bem próprio.

2 Mais uma vez, repise-se, a necessidade de recorrer a comentadores de modo reiterado advém da vacuidade das próprias determinações heideggerianas sobre o tema em Ser e Tempo, assim, faz-se premente a alusão indicativa de como esse assunto é abordado pelos comentadores e como ele pode ser ainda mais bem desenvolvido.

3 Por vezes, Hybris é o étimo grego que é compreendido como sendo um misto de insolência (no sentido de ser um insulto para com o outro) com malícia (Nyusztay, 2002, p. 37) - um modo de se comportar bastante próximo ao orgulho ferido por alguma outra coisa ou por alguém. todavia, o sentido a ser dado à selbstherrlich (e, consequentemente, a sua tradução por insolência) não possuem nenhum sentido moral, tal como é costume se dar ao ter grego em comento, tampouco com ele se confunde, não sendo um simples desvio de caráter para atender aos próprios desejos mais obscuros e às vicissitudes costumeiras.

$4 \mathrm{Ou}$ seja, uma compreensão pré-ontológica de si mesmo que demonstre esse caráter interpretativo perante os modos de ser coletivos.

$5 \mathrm{O}$ ser finito para Heidegger é aquele que se projeta no entendimento de que a existência acaba e que o homem morre, somente de acordo com essa perspectiva é que o horizonte do futuro 
(autêntico) se descortina ao Dasein.

6 A tradução de Schuld por "débito" é algo bastante discutido pelos comentadores de Heidegger. Zeljko Loparić (2002, p. 20), além de Márcia Schüback (tradutora da versão de Ser e Tempo em português, a qual foi usada de maneira basilar no trabalho em desenvolvimento) também mantém a tradução anteriormente referida. Todavia, há quem pontue, como o faz Cláudio Almir Dalbosco (2006, p. 1134), que a tradução apresentada acaba por ser detentora "de um peso demasiadamente teológico e, por isso, deixa tal expressão ainda carregada de um sentido ôntico não pensado por Heidegger ao formulála". Este comentador considera que a tradução de Schuld por "falta" como mais acertada porque mantém o sentido ontológico-existencial intencionado pelo autor de Ser e Tempo. Ainda que pesem tais ponderações, há de se notar que uma intencionalidade teológica, velada, diga-se de passagem, na leitura de Ser e Tempo não é algo hediondo, por isso meso, há de se compreender que não há nenhum desvio metodológico nas traduções de Loparić e de Schüback. 